\title{
Vegetation establishment improves topsoil properties and enzyme activities in the dry Aral Sea Bed, Kazakhstan
}

\section{Kazakistan'da kuruyan Aral Deniz Yatağında bitki örtüsü gelişiminin üst toprak özellikleri ve enzim aktivitelerini iyileştirmesi}

\author{
Jiae An (D), Seongjun Kim (D), Hanna Chang (D), Asia Khamzina (D), Yowhan Son (D) \\ Department of Environmental Science and Ecological Engineering, Graduate School, Korea University, Seoul 02841, Korea
}

Cite this paper as:

An, J., Kim, S., Chang, H., Khamzina, A., Son, Y., 2018 Vegetation establishment improves topsoil properties and enzyme activities in the dry Aral Sea Bed, Kazakhstan. Forestist 68(1): 1-6

Address for Correspondence:
Yowhan Son
e-mail:
yson@korea.ac.kr
Received Date:
12.12.2017
Accepted Date:
31.12 .2017
cc) (i) \$ This work is licensed under a Creative
commons Attribution-NonCommercial

\begin{abstract}
Afforestation has been conducted for preventing desertification in the desiccated Aral Sea Bed. The present study aimed to investigate the changes in topsoil properties and enzyme activities owing to vegetation establishment. In August 2017, soils were sampled from degraded area devoid of vegetation (DA), areas afforested in 2002 (P1) and 2013 (P2), and naturally vegetated area (NA) in the northern part of the exposed Aral Sea Bed. Soil water content, $\mathrm{pH}$, electrical conductivity, total $\mathrm{N}$ and organic $\mathrm{C}$ concentrations, exchangeable cation concentrations $\left(\mathrm{K}^{+}, \mathrm{Mg}^{2+}\right.$, $\mathrm{Ca}^{2+}$, and $\mathrm{Na}^{+}$), available $\mathrm{P}\left(\mathrm{P}_{2} \mathrm{O}_{5}\right)$ concentration, cation exchange capacity, and enzyme activities (acid phosphate, $\mathrm{N}$-acetyl-glucosaminidase, and $\beta$-glucosidase) were analyzed in the topsoil up to a depth of $10 \mathrm{~cm}$. Soil water content, total $\mathrm{N}$ and organic $\mathrm{C}$ concentrations, $\mathrm{K}^{+}$and $\mathrm{Mg}^{2+}$ concentrations, and enzyme activities were higher in P1 and NA than in DA. Moreover, no significant difference was found between P1 and NA in soil water content, total $\mathrm{N}$ and organic $\mathrm{C}$ concentrations, and some of the exchangeable cation concentrations. Our findings indicate that vegetation establishment increased the soil organic matter which is strongly associated with soil water content, organic C concentration, and overall soil fertility. The effects of plantation on soil amelioration are similar to those of natural vegetation in the long-term (15 years). Moreover, soil enzyme activities increased with rise in soil water content and total $\mathrm{N}$ and organic $\mathrm{C}$ concentrations in both vegetated areas (P1 and NA).
\end{abstract}

Keywords: Aral Sea, desertification, enzyme activity, restoration, soil amelioration

\section{ÖZ}

Kurumuş olan Aral Denizi Yatağında çölleşmeyi önlemek amacıyla ağaçlandırma yapıımıştır. Bu çalışma vejetasyon (bitkilendirme) çalışmasına bağlı olarak yüzey toprağı ve enzim aktivitelerindeki değişiklikleri araştırmak amacıyla yapıldı. Ağustos 2017'de, vejetasyondan yoksun çorak alandan (DA), 2002 (P1) ve 2013 (P2) yillarında ağaçlandırılmış alanlardan ve Aral Deniz Yatağının kuzey bölümündeki doğal bitki oluşumuna sahip alandan (NA) toprak numuneleri alındı. Toprağın su içeriği, $\mathrm{pH}$, elektrik iletkenliği, total $\mathrm{N}$ ve organik $\mathrm{C}$ seviyeleri, değiştirilebilir katyon seviyeleri $\left(\mathrm{K}^{+}, \mathrm{Mg}^{2+}, \mathrm{Ca}^{2+}, \mathrm{ve}\right.$ $\mathrm{Na}^{+}$), mevcut $\mathrm{P}\left(\mathrm{P}_{2} \mathrm{O}_{5}\right)$ seviyesi, katyon değişim kapasiteleri ve enzim aktiviteleri (fosfat asit, $\mathrm{N}$-asetilglukozaminidaz ve $\beta$-glukosidaz) yüzey toprağından $10 \mathrm{~cm}$ derinliğe kadar analiz edildi. Toprak su içeriği, total $\mathrm{N}$ ve organik $\mathrm{C}$ seviyeleri, $\mathrm{K}^{+}$ ve $\mathrm{Mg}^{2+}$ seviyeleri ve enzim aktivitelerinin P1 ve NA örneklerinde DA'ya göre daha yüksek olduğu görüldü. Ayrıca P1 ve NA arasında topraktaki su içeriği, total N ve organik C seviyeleri ve bazı değiştirilebilir katyon seviyeleri açııından anlamlı bir fark bulunmadı. Bulgularımıza göre vejetasyon çalışması, toprak su içeriği, organik C seviyesi ve genel toprak verimliliği ile oldukça ilişkili olan toprak organik maddesini artırdı. Toprağın iyileştirilmesinde bitkilendirmenin etkileri uzun dönemde (15 yıl) doğal vejetasyonun etkileriyle benzerdir. Ayrıca, toprağın enzim aktiviteleri toprağın su içeriği ve total $N$ ve organik C seviyelerindeki artışla P1 ve NA numunelerinde yükselmiştir.

Anahtar Kelimeler: Aral Denizi, çölleşme, enzim aktivitesi, restorasyon, toprağın iyileştirilmesi

\section{INTRODUCTION}

Desiccation of Aral Sea is considered one of the world's most serious environmental disasters in the recent past (Micklin, 2014). Aral Sea was the world's fourth-largest inland water body in 1960, with an area of nearly 67,000 $\mathrm{km}^{2}$ (Waltham and Sholji, 2001). However, diversion of the tributary rivers for large-scale irrigation for supporting the extensive cotton industry caused its depletion starting from the 1960s. Aral Sea split into two water bodies as northern Small Aral Sea and southern Large 
Aral Sea by the late 1980s, and the area decreased to 11,000 $\mathrm{km}^{2}$ in 2015 (Jin et al., 2017). The decreasing water level and the increasing salinity caused soil degradation, vegetation decline, and deterioration of rich and diverse shoreline ecosystems (Micklin, 2014). Furthermore, a large amount of salts affected the physical and chemical properties of soils which in turn affected plant growth and enzyme activities (Singh et al., 2012a).

Considering the pace and scale of the desertification in this region, vegetation establishment is regarded as a more appropriate approach for reducing the associated damage from soil salinization and salty dust storms than e.g. chemical methods (Salt et al., 1998; Van et al., 2005; Park et al., 2013). Although naturally vegetated regions are present, establishment of vegetation by natural processes takes a long time. Rehabilitation of the dried seabed through afforestation has been attempted in several restoration projects (Micklin, 2014) aiming to reduce soil erosion, thereby increasing nutrient concentration and soil organic matter and improving soil structure (Shirato et al., 2004; Yüksek and Yüksek, 2011). Nonetheless, time for soil amelioration and extent of the effects through afforestation varied (Shirato et al., 2004; Singh et al., 2012b; Zhang et al., 2013); therefore, the degree of soil recovery following afforestation should be monitored and evaluated (Shirato et al., 2004).

Detecting soil properties and enzyme activities can be relevant for understanding biological processes in soil recovery. The interactions between physical and chemical properties of soils and exchangeable cations affect plant growth by controlling nutrient availability. In addition, they contribute to the increase in soil fertility and creation of supportive microenvironments for plants and microorganisms (Zhang et al., 2013). The increase in concentrations of nutrients such as $\mathrm{P}, \mathrm{N}$, and organic $\mathrm{C}$ are good indicators of soil quality and productivity because they affect the physicochemical and biological properties of soil (Cao et al., 2011). Furthermore, soil enzymes play an important role in organic matter decomposition and nutrient cycling (Cao et al., 2011). Enzyme activities are highly sensitive to the changes derived from plantations of different species and management practices on degraded lands (Singh et al., 2012a). Therefore, soil enzyme activities are considered to be useful indicators of soil ecosystem function, including microbial functioning, fertility, biological diversity, productivity, resource requirements, and nutrient availability to plants (Caldwell, 2005; Sinsabaugh et al., 2009). Therefore, the simultaneous measurement of soil properties and enzyme activities are required for evaluating the effect of plants on soil biochemical processes. Moreover, the vegetation establishment contributes to the increase in soil water content and fertility, decrease in $\mathrm{pH}$ and electric conductivity, and induced changes in microbial activities (Singh et al., 2012a).

The present study aimed to investigate the effects of the vegetation establishment on soil properties and enzyme activities in Aral Sea Bed. To this end, we compared soil biochemical properties in a degraded area with afforested and naturally vegetated area. Thereafter, the soil in the afforested area was compared with that in the naturally vegetated area to specify the differences associated with the type of vegetation establishment.

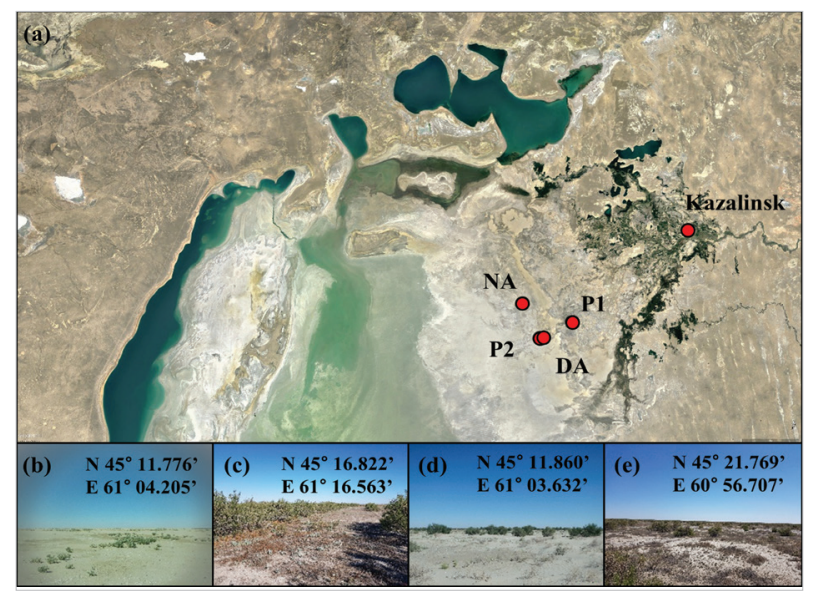

Figure 1. a-d. Location of the study area (a) and the photographs and GPS coordinates of study sites ( $b$ : degraded area (DA), c: area afforested in 2002 (P1), d: area afforested in 2013 (P2), and e: natural vegetation area (NA))

We hypothesized that (1) vegetation establishment ameliorates soils by reducing soil pH and salinity and enriching its fertility, (2) enzyme activities would increase after the vegetation establishment on degraded soil, and (3) the ameliorating effects on topsoil properties and enzyme activities differ between afforested and naturally vegetated areas.

\section{MATERIALS AND METHODS}

\section{Study Area}

The research area is located on the southwest of Kazalinsk (Figure 1) near northern Aral Sea. Four soil sampling sites were selected, i.e. degraded area (DA), without plant cover; plantation areas P1 and P2, where afforestation was carried out in 2002 and 2013, respectively; and a natural vegetation area (NA). Aral Sea shoreline has receded starting from 1970s in all the sites. The annual mean temperature of Kazalinsk is $7.5^{\circ} \mathrm{C}$ (Issanova and Abuduwaili, 2017), and the annual rainfall is less than $90 \mathrm{~mm}$ (Waltham and Sholji, 2001). Soil of the exposed bed of Aral Sea is dominated by solonchak and takyr (Breckle and Geldyeva, 2012) which are types of gray-brown desert soil characterized by high quantity of carbonates, low organic carbon content, and the presence of a superficial porous crust (Pachikin et al., 2014). The sampled soils were dominated by coarse sandy texture.

\section{Soil Sampling and Analyses}

After removing surface residues, soil samples were collected using a digging knife from three points at depths of 0-10 cm, and mixed in each of the four sites in August 2017. Soil water content was measured gravimetrically, after oven-drying fresh soil samples at $105^{\circ} \mathrm{C}$. The samples were air-dried at room temperature and passed through a sieve to remove sea shells prior to the analysis of soil chemical characteristics. Soil pH was measured using a refillable pH electrode (ROSS Ultra pH/ ATC Triode, Thermo Scientific, MA, USA) in a 1:5 soil-to-distilled water mixture with shaking for 1 hour. Electric conductivity ( $E C_{1.5}$ ) was measured by EC meter (Orion Star A212, Thermo Scientific, MA, USA), after shaking 
the 1:5 soil-to-distilled water mixture for 30 minutes. Total $\mathrm{N}$ concentration was determined by dry combustion at $1,000^{\circ} \mathrm{C}$ with an elemental analyzer (vario Macro, Elementar Analysensysteme GmbH, Langenselbold, Germany), and the soil organic C concentration was measured by the Walkley and Black wet digestion and titration method (Walkley and Black, 1934). Soil concentration of exchangeable cations $\left(\mathrm{K}^{+}, \mathrm{Mg}^{2+}, \mathrm{Ca}^{2+}\right.$, and $\left.\mathrm{Na}^{+}\right)$and available $\mathrm{P}$ $\left(\mathrm{P}_{2} \mathrm{O}_{5}\right)$ were measured using ICP-OES (730 series, Agilent Technologies Inc., CA, USA) after Mehlich 3 extraction. Cation exchange capacity (CEC) was calculated by adding up the total amount of exchangeable $\mathrm{K}^{+}, \mathrm{Mg}^{2+}, \mathrm{Ca}^{2+}$, and $\mathrm{Na}^{+}$measured.

Three enzyme activities in soil (acid phosphate (AP), N-acetyl-glucosaminidase (NAG), and $\beta$-glucosidase (BG)) were used to represent the degradation of main soil biochemical compounds (Table 1) (Sinsabaugh et al., 2009). These enzymes were measured by fluorometric method (DeForest, 2009) in black polystyrene 96-well microplates (300 $\mu \mathrm{L}$, SPL Life Sciences Co. Ltd, Pocheon-si, Korea), using substrate analogs linked to the fluorescent molecules of 4-methylumbelliferon (4-MUB, Sigma-Aldrich Co. Ltd, Yongin-si, Korea). For enzyme assays, soil suspension was prepared with $2 \mathrm{~g}$ soil and $100 \mathrm{~mL}$ of the Tris buffer (pH 8.0). The other procedures followed DeForest (2009), who used a strict order to incorporate the soil suspension, ref- erences, and substrates into the microplates. The microplates were coved and incubated at $25^{\circ} \mathrm{C}$ in the incubator for 4 hours. To terminate the reaction, $50 \mu \mathrm{L}$ of $0.2 \mathrm{~mol} \mathrm{~L}^{-1} \mathrm{NaOH}$ solution was added to each well. Fluorescence was measured at $355 \mathrm{~nm}$ excitation and $460 \mathrm{~nm}$ emission levels with a Multi-Detection Microplate Reader (Sense, HIDEX, Turku, Finland).

\section{Statistical Analysis}

One-way ANOVA was used for assessing the differences in soil water content, $\mathrm{pH}, \mathrm{EC}_{1.5}$, total $\mathrm{N}$ and soil organic $\mathrm{C}$ concentrations, concentrations of exchangeable cations and available P,CEC, and enzymes activities among the sites. Duncan's test was applied to indicate significantly different means $(p<0.05)$. All statistical analyses were performed using SAS 9.4 (SAS Institute, NC, USA).

\section{RESULTS AND DISCUSSION}

P1 and NA had higher soil water content (\% of weight) (DA: 2.46, P1: 6.93, and NA: 5.61; $p=0.0021)$, total $N$ and soil organic $C$ concentrations (\%) (DA: 0.01, P1: 0.05, and NA: 0.03; $p=0.0010$ and DA: 0.14, P1: 0.48, and NA: 0.38; $\mathrm{p}=0.0041$, respectively), and $\mathrm{K}^{+}$ and $\mathrm{Mg}^{2+}$ concentrations $\left(\mathrm{cmol}_{c} \mathrm{~kg}^{-1}\right)$ (DA: 0.71, P1: 1.49, and NA: 1.65; $p=0.0005$ and DA: 7.51, P1: 9.61, and NA: 11.03; $p=0.0097$, respectively) than those of DA (Table 2$)$. CEC $\left(\mathrm{cmol}_{\mathrm{c}} \mathrm{kg}^{-1}\right)$ was

Table 1. Soil enzymes assayed for activity with abbreviation and substrate, corresponding Sigma-Aldrich product number (Sigma no.), related elements, and enzyme functions

\begin{tabular}{|llccl}
\hline Enzyme (Abbreviation) & Substrate & Sigma no. & Related element & Enzyme function \\
\hline Acid phosphate (AP) & 4-MUB-phosphate & M8883 & $P$ & $\begin{array}{l}\text { Hydrolysis of phosphate from } \\
\text { phosphosaccharides and phospholipids }\end{array}$ \\
N-acetyl-glucosaminidase (NAG) & 4-MUB-N-acetyl- $\beta$-glucosaminide & M2133 & $N$ & Hydrolysis of chitin N-acetyl- $\beta$-glucosaminide \\
$\beta$-glucosidase (BG) & 4-MUB- $\beta$-D-glucopyranoside & M3633 & C & Hydrolysis of terminal $\beta$-D-glucosyl residues \\
\hline
\end{tabular}

Table 2. Soil properties of study sites

\begin{tabular}{|c|c|c|c|c|c|}
\hline \multirow[b]{2}{*}{ Soil properties } & \multicolumn{4}{|c|}{ Study site } & \multirow[b]{2}{*}{$\mathrm{p}$} \\
\hline & DA & P1 & $\mathrm{P} 2$ & NA & \\
\hline Soil water content (\% of weight) & $2.46(0.69)^{b}$ & $6.93(1.70)^{a}$ & $0.26(0.07)^{b}$ & $5.61(0.68)^{\mathrm{a}}$ & 0.0021 \\
\hline $\mathrm{pH}$ & $9.09(0.10)$ & $8.81(0.04)$ & $8.71(0.04)$ & $8.82(0.13)$ & 0.0835 \\
\hline $\mathrm{EC} 1: 5\left(\mathrm{dS} \mathrm{m}^{-1}\right)$ & $13.62(3.10)^{\mathrm{ab}}$ & $17.14(3.57)^{\mathrm{a}}$ & $5.87(1.41)^{b}$ & $21.61(4.06)^{\mathrm{a}}$ & 0.043 \\
\hline Total N (\%) & $0.01(0.00)^{b}$ & $0.05(0.01)^{\mathrm{a}}$ & $0.01(0.00)^{b}$ & $0.03(0.00)^{\mathrm{a}}$ & 0.0010 \\
\hline Organic C (\%) & $0.14(0.01)^{b}$ & $0.48(0.11)^{\mathrm{a}}$ & $0.09(0.00)^{b}$ & $0.38(0.04)^{\mathrm{a}}$ & 0.0041 \\
\hline $\mathrm{K}^{+}\left(\mathrm{cmolc} \mathrm{kg}^{-1}\right)$ & $0.71(0.10)^{\mathrm{b}}$ & $1.49(0.16)^{a}$ & $0.30(0.03)^{b}$ & $1.65(0.24)^{\mathrm{a}}$ & 0.0005 \\
\hline $\mathrm{Mg}^{2+}\left(\mathrm{cmolc} \mathrm{kg}^{-1}\right)$ & $7.51(0.53)^{b c}$ & $9.61(1.23)^{a b}$ & $4.94(0.26)^{c}$ & $11.03(1.38)^{\mathrm{a}}$ & 0.0097 \\
\hline $\mathrm{Ca}^{2+}\left(\mathrm{cmolc} \mathrm{kg}^{-1}\right)$ & $82.50(11.26)$ & $87.23(1.21)$ & $71.37(4.43)$ & $103.36(2.60)$ & 0.089 \\
\hline $\mathrm{Na}^{+}\left(\mathrm{cmolc} \mathrm{kg}^{-1}\right)$ & $9.19(2.15)$ & $10.71(2.63)$ & $3.27(0.33)$ & $13.28(6.16)$ & 0.1654 \\
\hline Available $\mathrm{P}\left(\mathrm{P}_{2} \mathrm{O}_{5}\right)(\mathrm{ppm})$ & $2.22(0.74)^{b}$ & $46.80(17.52)^{\mathrm{a}}$ & $2.64(0.18)^{b}$ & $10.81(1.58)^{b}$ & 0.0359 \\
\hline CEC (cmolc kg-1) & $99.92(8.74)^{\mathrm{bc}}$ & $109.04(5.18)^{a b}$ & $79.87(4.90)^{c}$ & $129.32(5.18)^{a}$ & 0.0087 \\
\hline
\end{tabular}


Table 3. Acid phosphatase (AP), N-acetyl-glucosaminidase (NAG), and $\beta$-glucosidase (BG) enzyme activities ( $\mathrm{nmol} / \mathrm{h} / \mathrm{g}$ soil) in study sites

\begin{tabular}{|c|c|c|c|c|c|}
\hline \multirow[b]{2}{*}{ Enzyme } & \multicolumn{4}{|c|}{ Study site } & \multirow[b]{2}{*}{$\mathrm{p}$} \\
\hline & DA & P1 & P2 & NA & \\
\hline AP $\left(n m o l ~ h^{-1} g^{-1}\right.$ soil $)$ & $0.69(0.25)^{c}$ & $36.68(6.32)^{b}$ & $0.90(0.29)^{c}$ & $50.30(2.83)^{\mathrm{a}}$ & $<0.0001$ \\
\hline NAG (nmol h-1 $\mathrm{g}^{-1}$ soil) & $0.00(0.00)^{\mathrm{b}}$ & $12.13(4.20)^{\mathrm{a}}$ & $0.08(0.01)^{b}$ & $8.07(2.15)^{\mathrm{a}}$ & 0.015 \\
\hline BG (nmol h-1 $\mathrm{g}^{-1}$ soil) & $0.00(0.00)^{b}$ & $49.84(7.77)^{\mathrm{a}}$ & $0.78(0.27)^{b}$ & $63.18(6.84)^{\mathrm{a}}$ & $<0.0001$ \\
\hline
\end{tabular}

significantly higher in NA than in DA (DA: 99.92 and NA: 129.32; $\mathrm{p}=0.0087$ ), and $\mathrm{P}_{2} \mathrm{O}_{5}$ concentration (ppm) was significantly higher in P1 than in the other sites (DA: 2.22, P1: 46.80, P2: 2.64, and NA: 10.81; $P=0.0359)$. Soil $\mathrm{pH}$ did not differ significantly among the sites, all of which had alkaline soils ( $\mathrm{pH}$ 8.71-9.09). No significant difference in $\mathrm{EC}_{1: 5}$ was found in P1, P2, and NA, as compared with DA. Analysis of the effect of vegetation establishment for different durations on enzyme activities ( $\mathrm{nmol}$ $\mathrm{h}^{-1} \mathrm{~g}^{-1}$ soil) showed that AP (DA: 0.69, P1: 36.68, P2: 0.90, and NA: 50.30; $P<0.0001$ ), NAG (DA: 0.00, P1: 12.13, P2: 0.08, and NA: 8.07; $p=0.015)$, and $B G(D A: 0.00, P 1: 49.84, P 2: 0.78$, and NA: 63.18; $p<0.0001)$ were significantly higher in the vegetated areas ( $P 1$ and NA) than in the degraded area (DA), whereas the difference between DA and P2 was not significant (Table 3).

Consistent with the first hypothesis, our results combined point at an increase in soil nutrient because of long-term vegetation establishment, either naturally (since 1970s) or by afforestation (since 2002). Positive interaction of vegetation with soil water content has been observed previously (D'Odorico et al., 2007; Singh et al., 2012b). Soil water content could increase in vegetated areas owing to reduction in air and soil temperature and lower evaporation from the soil surface shaded by plants (Kizito et al., 2006). In contrast, soils in degraded area tend to dry out rapidly owing to the higher exposure to solar irradiance, which causes greater soil water evaporation (D'Odorico et al., 2007). In addition to the shading effect, vegetation may improve soil infiltration capacity owing to the action of roots (D'Odorico et al., 2007). However, soil water depletion has been reported in the case of large-scale afforestation in drylands (Jackson et al., 2005).

In addition, enrichment of fertility is a well-known indicator of soil amelioration (Singh et al., 2012b). The superior total $\mathrm{N}$ and organic $\mathrm{C}$ concentrations in $\mathrm{P} 1$ than in DA might be due to foliar litter inputs, fine root turnover (Singh et al., 2012b), and formation of humus (Jobbágy and Jackson, 2004). Exchangeable cation concentration in the study sites tended to differ according to the type of cation. A previous study on coastal sand dunes reported a higher concentration of $\mathrm{K}^{+}$in the topsoil of afforested areas, whereas that of $\mathrm{Na}^{+}$did not change because of the differential importance of cations for plants (Jobbágy and Jackson, 2004). Exchangeable $\mathrm{K}^{+}$is known to accumulate in surface soils because of upward transport by plants and plant litter decomposition (Jobbágy and Jackson, 2001).
Reduction of $\mathrm{pH}$ by natural or artificial vegetation establishment, as reported in studies on amelioration of sodic soils (Singh et al., 2012b) was not relevant in the present study on primary vegetation succession and afforestation in the Aral Sea Bed. In addition, the uptake of nutrient cations by roots requires the reverse flux of $\mathrm{H}^{+}$, which could decrease the $\mathrm{pH}$ of soil in vegetated areas (Nilsson et al., 1982). However, the absolute amount of nutrients is very low in this region (Table 2). Therefore, longer time might be required for nutrient absorption and lowering of $\mathrm{pH}$ by vegetation. Several previous studies, which reported that the success of plantations in ameliorating saline-alkali land depends on the duration time of the plantation and the corresponding amount and quality of litter deposited (Singh et al., 1994; Singh et al., 2012b; Zhang et al., 2013). Particularly, a significant change in $\mathrm{pH}$ with plantation duration has been reported (Zhang et al., 2013). Shirato et al. (2004) has specified that approximately 20 years is needed for soil recovery because soil properties change slowly. Previous afforestation studies in Central Asia revealed either decrease (Hbirkou et al., 2011) or increase (Khamzina et al., 2016) in soil salinity following vegetation establishment. In the Aral Sea Bed, both, long-term vegetated and exposed areas exhibited high salinity, suggesting that abiotic factors such as groundwater oscillations might play a role in the soil salinity dynamics (Schachtsiek et al., 2014).

No statistically significant difference was found between P1 and NA for most of the soil properties studied, which indicates similarity in the state of amelioration in spite of the longer duration of plant cover in NA than in P1. Increasing soil organic C concentration during the vegetation restoration process is associated with the increase in soil CEC (Shirato et al., 2004). The variation in exchangeable cation concentrations and CEC would change along with soil chemical properties, such as pH, C and N concentrations, and biological properties, which affect the availability of nutrients to plants (Zhang et al., 2013).

Similar to the second hypothesis, increases in soil enzyme activities, which reflect that microbial activity in the soil, might be promoted by the plantation. Enzyme activities of soil are very early and sensitive indicators for changes during restoration (Cao et al., 2011), and they are affected by various soil properties, such as soil water content and nutrient supplements (Davidson and Janssens, 2006; Steinweg et al., 2013). Similarly, distinct correlations of enzyme activities with soil water content and total $\mathrm{N}$ and organic C concentrations in the present study (Figure 2). In- 


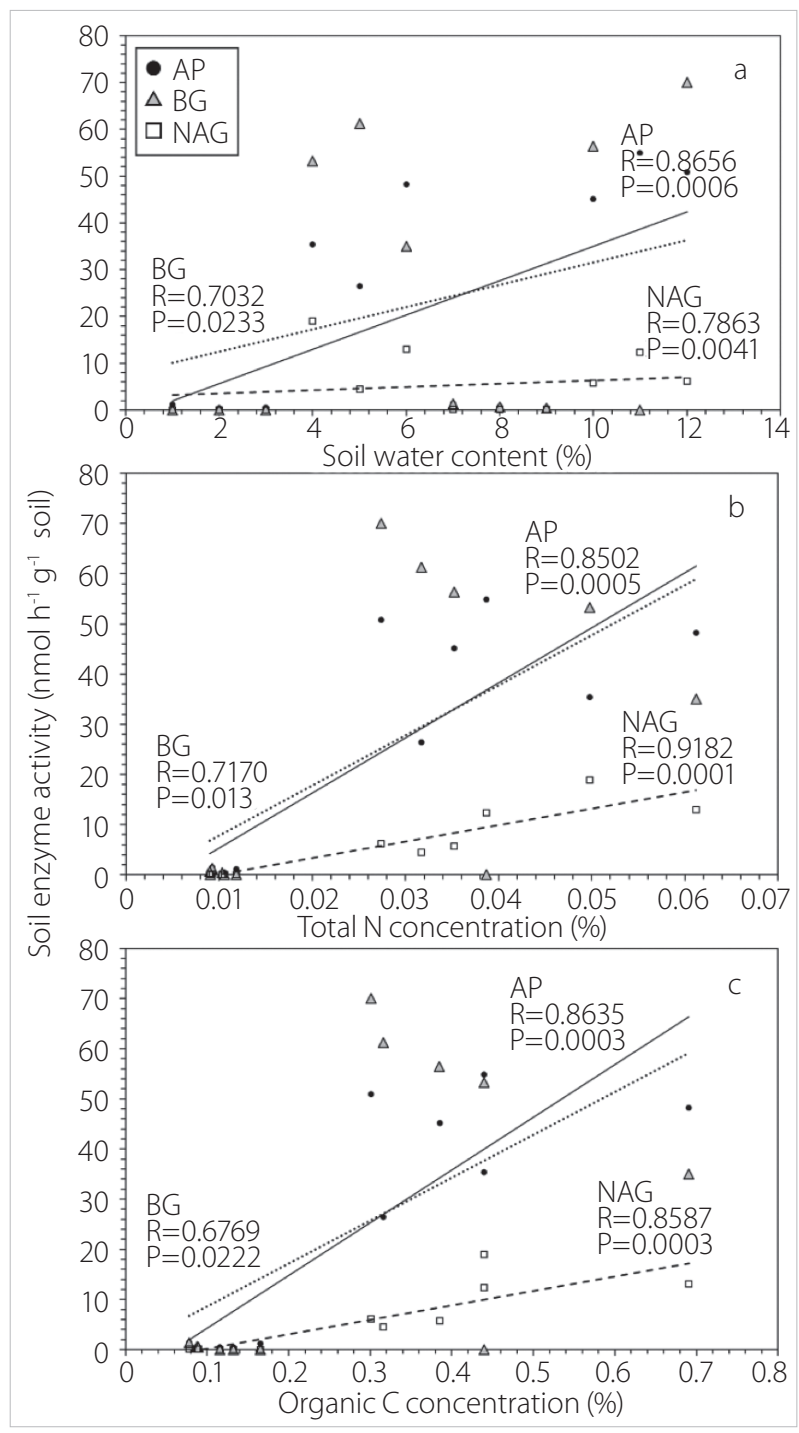

Figure 2. a-c. Correlations of enzyme activity $\left(\mathrm{nmol} \mathrm{h}^{-1} \mathrm{~g}^{-1}\right.$ soil) (Acid phosphatase (AP), N-acetyl-glucosaminidase (NAG), and $\beta$-glucosidase (BG)) and soil water content (a) and total $\mathrm{N}$ (b) and organic $\mathrm{C}$ concentrations (\%) (c)

creases in soil organic $C$ concentration and water content might be favorable for soil microbes, thereby promoting the secretion and activity of enzymes (Sileshi et al., 2007). However, enzyme production could be stimulated with increase in the diffusion of substrate or increase in bioavailability of nutrients in the soil (Davidson and Janssens, 2006; Steinweg et al., 2013). Even if nutrients available in soil were sufficient for microbial activity, available nutrient diffusion limitations in environments with low soil moisture content can reduce the production of microbial enzymes (Steinweg et al., 2013). Thus, enhanced microbial activity in vegetated areas can contribute to plant productivity through the regulation of mineral nutrient availability (Van Der Heijden et al., 2008).

Nevertheless, both positive and negative effects of plantation with soil water and salinity have been reported (Qi et al., 2015), whereas the results of the present study are based on the oneoff, small-scale soil survey. Therefore, recurrent monitoring at larger spatial scales would be required for capturing the spatial heterogeneity in soil properties, which are dependent on vegetation distribution (Li et al., 2011), and the manifestation of the detailed effects of soil amelioration by vegetation establishment after plantation.

\section{CONCLUSION}

Distinct effects of vegetation establishment on soil chemical characteristics and microbial enzyme activities were found on the desiccated bed of Aral Sea. The changes were pronounced in P1, which was afforested in 2002, and in NA, which was naturally vegetated. However, no change was found in P2, the recently planted area (2013) as compared with the degraded area. Vegetation establishment increased soil organic matter, soil organic C concentration, and soil water content. These changes might have been responsible for the increase in CEC and nutrient retention capacity, resulting in increases in $\mathrm{K}^{+}$ and $\mathrm{Mg}^{2+}$ concentrations. Improvements in soil properties, such as increases in soil water content, nutrient concentrations, and enzyme activities were comparable between P1 and NA. Evidently, plantation exerts similar amelioration effects as those exerted by natural vegetation, subject to the availability of sufficient time for vegetation development. Furthermore, afforestation appears to be quicker method that is as effective as natural vegetation establishment. Therefore, rehabilitation through plantation might be recommended for establishing soil cover and reinforcing the process of the natural succession.

Acknowledgement: This study was carried out with the support of Korea Forest Service (2012021C10-1718-AA01).

\section{REFERENCES}

- Breckle, S.W., Geldyeva, G.V., 2012. Dynamics of the Aral Sea in geological and historical times. In: Breckle, S.W., Wucherer, W., Dimeyeva, L., Ogar, N. (Eds.), Aralkum - A Man-Made Desert, Springer, Berlin, Heidelberg, pp. 13-35. [CrossRef]

- Caldwell, B.A., 2005. Enzyme activities as a component of soil biodiversity: A review. Pedobiologia 49(6): 637-644. [CrossRef]

- Cao, C., Jiang, S., Ying, Z., Zhang, F., Han, X., 2011. Spatial variability of soil nutrients and microbiological properties after establishment of leguminous shrub Caragana microphylla Lam. Plantation on sand dune in the Horqin Sandy Land of Northeast China. Ecological Engineering 37(10): 1467-1475. [CrossRef]

- D'Odorico, P., Caylor, K., Okin, G.S., Scan, T.M., 2007. On soil moisture - vegetation feedbacks and their possible effects on the dynamics of dryland ecosystems. Journal of Geophysical Research 112: G04010. [CrossRef]

- Davidson, E.A., Janssens, I.A., 2006. Temperature sensitivity of soil carbon decomposition and feedbacks to climate change. Nature 440(7081): 165-173. [CrossRef]

- DeForest, J.L., 2009. The influence of time, storage temperature, and substrate age on potential soil enzyme activity in acidic forest soils using MUB-linked substrates and L-DOPA. Soil Biology and Biochemistry 41(6): 1180-1186. [CrossRef] 
- Hbirkou, C., Martius, C., Khamzina, A., Lamers, J.P.A., Welp, G., Amelung, W., 2011. Reducing topsoil salinity and raising carbon stocks through afforestation in Khorezm, Uzbekistan. Journal of Arid Environments 75(2): 146-155. [CrossRef]

- Issanova, G., Abuduwaili, J., 2017. Dust storms in Central Asia and Kazakhstan: Regional division, frequency and seasonal distribution. In: Issanova, G., Abuduwaili, J, Aeolian Process as Dust Storms in The Deserts of Central Asia and Kazakhstan, Springer, Singapore, pp. 87-109. [CrossRef]

- Jackson, R.B., Jobbágy, E.G., Avissar, R., Roy, S.B., Barrett, D.J., Cook, C.W., Farley, K.A., le Maitre, D.C., McCarl, B.A., Murray, B.C., 2005. Trading water for carbon with biological carbon sequestration. Science 310(5756): 1944-1947. [CrossRef]

- Jin, Q., Wei, J., Yang, Z.L., Lin, P., 2017. Irrigation-induced environmental changes around the Aral Sea: An integrated view from multiple satellite observations. Remote Sensing 9(9): 900, doi: 10.3390/ rs9090900 [CrossRef]

- Jobbágy, E.G., Jackson, R.B., 2001. The distribution of soil nutrients with depth: Global patterns and the imprint of plants. Biogeochemistry 53(1): 51-77. [CrossRef]

- Jobbágy, E.G., Jackson, R.B., 2004. The uplift of soil nutrients by plants: Biogeochemical consequences across scales. Ecology 85(9): 2380-2389. [CrossRef]

- Khamzina, A., Lamers, J.P.A., Martius, C., 2016. Above- and belowground litter stocks and decay at a multi-species afforestation site on arid, saline soil. Nutrient Cycling in Agroecosystems 104(2): 187199. [CrossRef]

- Kizito, F., Dragila, M., Sène, M., Lufafa, A., Diedhiou, I., Dick, R.P., Selker, J.S., Dossa, E., Khouma, M., Badiane, A., Ndiaye, S., 2006. Seasonal soil water variation and root patterns between two semi-arid shrubs co-existing with Pearl millet in Senegal, West Africa. Journal of Arid Environments 67(3): 436-455. [CrossRef]

- $\quad$ Li, C., Li, Y., Ma, J., 2011. Spatial heterogeneity of soil chemical properties at fine scales induced by Haloxylon ammodendron (Chenopodiaceae) plants in a sandy desert. Ecological Research 26(2): 385394. [CrossRef]

- Micklin, P., 2014. The Aral Sea. Springer, Berlin, Heidelberg. [CrossRef]

- $\quad$ Nilsson, S.I., Miller, H.G., Miller, J.D., 1982. Forest growth as a possible cause of soil and water acidification: An examination of the concepts. Oikos 39(1): 40-49. [CrossRef]

- Pachikin, K., Erokhina, O., Funakawa, S., 2014. Soils of Kazakhstan, their distribution and mapping. In: Mueller, L., Saparov, A., Lischeid, G. (Eds.), Novel Measurement and Assessment Tools for Monitoring and Management of Land and Water Resources in Agricultural Landscapes of Central Asia, Springer, Cham, pp. 519-533. [CrossRef]

- $\quad$ Park, K.H., Qu, Z.Q., Wan, Q.Q., Ding, G.D., Wu, B., 2013. Effects of enclosures on vegetation recovery and succession in Hulunbeier steppe, China. Forest Science and Technology 9(1): 25-32. [CrossRef]

- Qi, Y., Yang, F., Shukla, M.K., Pu, J., Chang, Q., Chu, W., 2015. Desert soil properties after thirty years of vegetation restoration in northern Shaanxi province of China. Arid Land Research and Management 29(4): 454-472. [CrossRef]
Salt, D.E., Smith, R.D., Raskin, I., 1998. Phytoremediation. Annual Review of Plant Physiology and Plant Molecular Biology 49(1): 643-668. [CrossRef]

- $\quad$ Schachtsiek, T., Lamers, J.P.A., Khamzina, A., 2014. Early survival and growth of six afforestation species on abandoned cropping sites in irrigated drylands of the Aral Sea Basin. Arid Land Research and Management 28(4): 410-427. [CrossRef]

- Shirato, Y., Taniyama, I., Zhang, T.H., 2004. Changes in soil properties after afforestation in Horqin Sandy Land, North China. Soil Science and Plant Nutrition 50(4): 537-543. [CrossRef]

- $\quad$ Sileshi, G., Akinnifesi, F.K., Ajayi, O.C., Chakeredza, S., Kaonga, M., Matakala, P.W., 2007. Contributions of agroforestry to ecosystem services in the miombo eco-region of eastern and southern Africa. African Journal of Environmental Science and Technology 1(4): 68-80.

- $\quad$ Singh, G., Singh, N.T., Abrol, I.P., 1994. Agroforestry techniques for the rehabilitation of degraded salt-affected lands in India. Land Degradation and Rehabilitation 5(3): 223-242. [CrossRef]

- $\quad$ Singh, K., Pandey, V.C., Singh, B., Singh, R.R., 2012a. Ecological restoration of degraded sodic lands through afforestation and cropping. Ecological Engineering 43: 70-80. [CrossRef]

- Singh, K., Singh, B., Singh, R.R., 2012b. Changes in physico-chemical, microbial and enzymatic activities during restoration of degraded sodic land: Ecological suitability of mixed forest over monoculture plantation. Catena 96: 57-67. [CrossRef]

- Sinsabaugh, R., Hill, B.H., Shah, J.J.F., 2009. Ecoenzymatic stoichiometry of microbial organic nutrient acquisition in soil and sediment. Nature 462(7274): 795-798. [CrossRef]

- $\quad$ Steinweg, J.M., Dukes, J.S., Paul, E.A., Wallenstein, M.D., 2013. Microbial responses to multi-factor climate change: Effects on soil enzymes. Frontiers in Microbiology 4: 146. [CrossRef]

- Van Der Heijden, M.G.A., Bardgett, R.D., Van Straalen, N.M., 2008. The unseen majority: Soil microbes as drivers of plant diversity and productivity in terrestrial ecosystems. Ecology Letters 11(3): 296310. [CrossRef]

- Van, D.T., Lee, D.K., Van, T.H., 2005. Rehabilitation of the native tree species in the forest plantations and denuded hills of Namlau commune in Sonla province, Vietnam. Forest Science and Technology 1(1): 51-58. [CrossRef]

- Walkley, A., Black, I.A., 1934. An examination of the Degtjareff method for determining soil organic matter, and a proposed modification of the chromic acid tiltration method. Soil Science 37(1): 29-38 [CrossRef]

- Waltham, T., Sholji, I., 2001, The demise of the Aral Sea - an environmental disaster. Geology Today 17(6): 218-228. [CrossRef]

- Yüksek, T., Yüksek, F., 2011. The effects of restoration on soil properties in degraded land in the semi-arid region of Turkey. Catena 84(1): 47-53. [CrossRef]

- Zhang, Y.G., Xu, Z.W., Jiang, D.M., Jiang, Y., 2013. Soil exchangeable base cations along a chronosequence of Caragana microphylla plantation in a semi-arid sandy land, China. Journal of Arid Land 5(1): 42-50. [CrossRef] 